\title{
Quarto Congresso Ibero-Americano em Investigação Qualitativa
}

institucional.us.es/ambitos/

Isabel Pinho, Ronaldo Nunes Linhares e António Pedro Costa

Editores del monográfico

O monográfico de Investigação Qualitativa em Comunicação inserido neste número da Ámbitos. Revista Internacional de Comunicación contém 6 artigos selecionados pela comissão organizadora e científica do $4^{\circ}$ Congresso Ibero-Americano em Investigação Qualitativa (CIAIQ2015), de entre os melhores trabalhos de investigação da conferência relacionados com as temáticas da Revista. Os artigos deste número foram estendidos e aprofundados em relação às versões publicadas nas atas do CIAIQ2015.

O CIAIQ2015 decorreu de 5 a 7 de agosto de 2015 na Universidade Tiradentes em Aracaju, Brasil. A conferência recebeu um total de 464 submissões de artigos, envolvendo 906 autores de 17 países. Cada artigo foi submetido a um processo de revisão double-blind por uma comissão científica composta por elementos altamente qualificados nas áreas científicas do congresso.

O primeiro artigo, Representaciones de la memoria religiosa en el movimiento de los focolares, de Augustina Adela Zaros (Universidade de Padova, Itália), procura compreender a dinâmica de um movimento religioso na Itália e Argentina, nas suas dimensões da participação transnacional e local dos seus membros. A nível metodológico recorre à recolha de dados através de entrevistas e de fotos.

O segundo artigo, Cidadania, subcidadania e opinião pública: uma leitura critica das mídias brasileiras e portuguesas, da autoria de Simone Antoniaci Tuzzo (Universidade Federal de Rio de Janeiro), procura analisar os significados da palavra cidadania em dois países que partilham a mesma língua. A diferença da significação linguística do conceito reflete o contexto socio-histórico e os diversos espaços geográficos e territoriais.

O artigo seguinte, Construcción del concepto audiencia como objeto de estudio en la modernidad contemporánea. Una aproximación teórica, epistemológica y metodológica con foco en la tv pública, é uma contribuição da Universidade a República (Uruguai), cujos autores José Henrique Fernández e Ana Marta Martínez, apresentam uma discussão teórica e epistemológica que suporta o desenvolvimento de um projeto que visa uma metodologia específica no estudo de audiências.

O quarto artigo, A festa do Divino Espirito Santo em Santa Cruz de Goiás. Um universo rico de manifestações culturais, dos autores Liberalina Teodoro de Rezende, Sandro Dutra e Silva, Giovana Galvão Tavares, Maria Idelma Vieira D'abadia e Abadia de Lourdes da Cunha, estudam um legado ibérico, uma festa com os seus usos e costumes, a sua arte, a sua religião, a sua língua e o seu folclore. As manifestações culturais envolvem eventos, personagens, detalhes, sons e cores diversas.

O quinto artigo, Nota como exemplar textual do discurso de uma mídia corporativa, é uma contribuição sobre a importância da comunicação eficaz para implementar estratégias empresariais de modo a envolver todos os interessados. Os autores, Hélder Uzêda Castro e Marta Cardoso de Andrade, defendem a necessidade de se analisar texto/discursos presentes no cotidiano e circulantes na sociedade atual. Neste estudo a análise recai numa nota de uma revista empresarial publicada por uma instituição bancária privada.

O último artigo, Las comunicación de la innovación de las agencias de medios. Big Data en las webs propias, apresenta um estudo exploratório que procura observar os websites empresariais das 20 principais agências de publicidade, sobre o grau de utilização. As suas autoras, Natalia Papi Gálvez e Raquel GarcíaBonal refletem ainda sobre as fraquezas, as ameaças, os pontos fortes e as oportunidades da utilização de Big Data nestas agências. 
sucesso da conferência CIAIQ2015 e com a produção deste monográfico, incluindo os participantes, autores, comissão organizadora e científica, apoios, equipa editorial, entre muitos outros. Através do seu interesse, participação e da qualidade e rigor do seu trabalho científico, agora publicado na Ámbitos. Revista Internacional de Comunicación, esperamos que possa ser promovida a expansão da investigação qualitativa numa área tão importante.

Ámbitos. Revista Internacional de Comunicación, n.31, edición de invierno, 2016. 